\title{
Review of analytical models for estimating the bearing capacity of wooden beams reinforced with fiber composites
}

\author{
Damian Jończyk ${ }^{1}$, Marlena Rajczyk ${ }^{2}$
}

\begin{abstract}
:
The use of composites to strengthen wooden structures is currently a popular construction solution. Despite the popularity of the solution, there are still no normative regulations specifying the methods of estimating the load-bearing capacity of wooden elements reinforced with composites. It is possible to use numerical methods, but it is a relatively laborious method. Due to the lack of normative requirements, engineers designing composite beams must use the methods presented in the literature. The article presents an overview of the most popular analytical methods for estimating the load-bearing capacity of reinforced wooden elements.
\end{abstract}

\section{KEYWORDS}

wood; FRP; fiber composites; computational models

\section{Introduction}

An important issue in the case of designing elements for which there are no normative rules is the possibility of using other calculation algorithms to estimate the load capacity. It is important that in the case of this type of calculation methods, the complexity of both the adopted assumptions and mathematical calculation procedures is small. Analytical methods for estimating the load-bearing capacity of wooden elements reinforced with steel and with attached wooden elements were presented by Jasieńko [1], while those reinforced with composites Nowak [2]. Moreover, Nowak proposed a proprietary method of estimating the load-bearing capacity of wooden beams reinforced with CFRP tapes. Currently, the most frequently presented methods in the literature are methods using equivalent geometric and material characteristics [3] and the method based on the balance of forces in the cross-section, presented in [4,5].

The aim of the article is to present the most popular and effective methods of estimating the bearing capacity of wooden beams reinforced with fiber composites. The presented methods can be used by engineers to design the above-mentioned elements, and there is no collective study containing a list of the discussed methods.

The article presents the main assumptions of each of the load capacity estimation methods and presents the necessary formulas to perform calculations for each of the methods, which, according to the authors, are of practical importance in designing.

\footnotetext{
${ }^{1}$ Czestochowa University of Technology, Faculty of Civil Engineering, ul. Akademicka 3, 42-218 Częstochowa, e-mail: damian.jonczyk@pcz.pl, orcid id: 0000-0003-2161-4768

2 Czestochowa University of Technology, Faculty of Civil Engineering, ul. Akademicka 3, 42-218 Częstochowa, e-mail: marlena.rajczyk@pcz.pl, orcid id: 0000-0002-4893-0931
} 


\section{Analytical models}

\subsection{The method proposed by Nowak}

The basic assumption of the method presented in [2] is the fact that after reaching the ultimate load capacity $M_{\mathrm{gr}}(\mathrm{N} \cdot \mathrm{m})$, the cross-section undergoes total stress. The parameter $\alpha$ presented below is a measure of the cross-sectional effort for the interval $\left(0, M_{\mathrm{gr}}\right)$

$$
\alpha=\frac{M}{M_{\mathrm{gr}}}
$$

where $M$ - value of the bending moment, $\mathrm{N} \cdot \mathrm{m}$.

In the case of assuming any value of the $\alpha$ coefficient in the range from 0 to 1 , the relationship between the deformation $\varepsilon$ and the stress $\sigma(\mathrm{Pa})$ can be presented in the form:

$$
\sigma(z, \alpha)=K_{\alpha} \varepsilon(z, \alpha)
$$

where $K_{\alpha}$ - correction factor, Pa.

Assuming the above assumption, the relation $0 \leq M \leq M_{\mathrm{gr}}$ occurs for the load of the crosssection with moment, and the $K_{\alpha}$ coefficient can be determined on the basis of the formula (3)

$$
K_{\alpha}=\frac{M}{\int \varepsilon(z, \alpha) z d A}
$$

The bending section stiffnesses can be presented for the respective ranges in the form:

- for the elastic range $0 \leq \alpha \leq \alpha \mathrm{sp}$ :

$$
B_{\alpha}=E_{\mathrm{sp}} I
$$

- for the inelastic range $\alpha_{\mathrm{sp}} \leq \alpha \leq 1$ :

$$
B_{\alpha}=K_{\alpha} I
$$

where: $B_{\alpha}$ - the stiffness of the wooden section $\left[\mathrm{N} \cdot \mathrm{m}^{2}\right] ; E_{\mathrm{sp}}$ - modulus of longitudinal elasticity [Pa]; $I$ - moment of inertia of a wooden section $\left[\mathrm{m}^{4}\right]$.

Using formulas (4) and (5), it is possible to determine the effect of the nonlinear work of the element with the use of reduced bending stiffness, and thus the effect of nonlinearity on the deformed axis can also be determined. Substituting the variable $x$ for $\alpha$, it is possible to write the approximate equation of the axis of the deformed beam:

$$
\frac{d^{2} z}{d x^{2}}=-\frac{M(x)}{B(x)}
$$

Using the $K_{\alpha}$ coefficient, the mean stresses can be determined:

$$
\begin{aligned}
& \sigma_{\text {śr }}=K_{\alpha} \varepsilon_{\text {śr }} \\
& \sigma_{\text {śr }}=K_{\alpha} \varepsilon_{\text {śr }}=E_{\text {sp }} \varepsilon_{\text {śr }}
\end{aligned}
$$

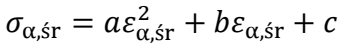

$$
\begin{aligned}
& \sigma_{\text {śr }}(\alpha)=K(\alpha) \varepsilon_{\text {śr }}(\alpha) \\
& \sigma_{\text {śr }}(\alpha)=f(\alpha)
\end{aligned}
$$




\subsection{Method using the equivalent geometric characteristics of the cross-section}

In this model it is initially assumed that: the reinforcement material is treated like wood, but the cross-section at the location of the reinforcement is increased to take account of the reinforcement; the shear strength of the weld is not exceeded; the element may be damaged by cutting the wood or by destroying the tape [2]. The above-mentioned increase in the dimensions of the cross-section is carried out by determining the imported width $b_{z}(\mathrm{~m})$, determined according to the formula:

$$
b_{z}=b_{f} \frac{E_{f}}{E_{0, \text { mean }}}
$$

The equivalent values of the moment of inertia and the bending strength index are determined according to formulas (13) and (14):

$$
\begin{gathered}
I_{z}=I_{d} \frac{1+4 n \mu}{1+n \mu} \\
W_{z}=\frac{I_{d}(1+4 n \mu)}{h_{c}(1+n \mu)}
\end{gathered}
$$

where: $b_{f}$ - width of the reinforcement strip [m]; $E_{f}$ - modulus of elasticity of the reinforcement material $[\mathrm{Pa}] ; E_{0, \text { mean }}$ - wood elastic modulus $[\mathrm{Pa}] ; I_{z}$ - equivalent moment of inertia $\left[\mathrm{m}^{4}\right]$; $I_{d}$ - moment of inertia of a wooden beam $\left[\mathrm{m}^{4}\right] ; n=E f /$ E0, mean; $\mu$ - percentage of reinforcement; $W_{z}$ - equivalent bending strength index $\left[\mathrm{m}^{3}\right] ; h_{c}$ - distance from the compression edge to the neutral axis $[\mathrm{m}]$.

Normal stresses $\sigma(\mathrm{Pa})$ and tangential stresses $\tau(\mathrm{Pa})$ are calculated in the classical way according to the formulas:

$$
\begin{gathered}
\sigma=\frac{M y}{I_{z}} \leq f_{\mathrm{m}, \mathrm{d}} \\
\tau=\frac{T S_{z}}{I_{z} b} \leq f_{\mathrm{v}, \mathrm{d}}
\end{gathered}
$$

where: $M$ - bending moment $[\mathrm{N} \cdot \mathrm{m}] ; y$ - coordinate [m]; $T$ - shear force $[\mathrm{N}] ; S_{z}$ - static moment $\left[\mathrm{m}^{3}\right] ; f_{\mathrm{m}, \mathrm{d}}-$ design bending strength of timber $[\mathrm{Pa}] ; f_{\mathrm{v}, \mathrm{d}}-$ design shear strength of wood $[\mathrm{Pa}]$.

The static moment is determined on the basis of:

$$
S_{z}=\frac{b h^{2}}{8}(1+n \mu)
$$

\subsection{Method with the use of substitute material characteristics of the cross-section}

In this model, Fossetti et al. [3] assumed that the extreme lamellae are made of $m_{1}$ material with $E_{1}(\mathrm{~Pa})$ modulus, while the middle lamellas are made of $m_{0}$ material, $E_{0}(\mathrm{~Pa})$. The effective moment of inertia of the reinforced beam $I_{t, r}\left(\mathrm{~m}^{4}\right)$ is expressed by the product of the moment of inertia for the unreinforced beam $I_{t}\left(\mathrm{~m}^{4}\right)$ and the correction factor $\beta_{r}$ as shown in Equation (18). Moment of inertia for the beam considering the position of the axis for the neutral value is shown in Equation 19.

$$
\begin{gathered}
I_{\mathrm{t}, \mathrm{r}}=\beta_{r} I_{t} \\
I_{\mathrm{t}, \mathrm{r}}=I_{t}+b h[n-(n-1) \gamma]\left(\frac{h}{2}-x_{\mathrm{G}, \mathrm{r}}\right)^{2}+A_{r} \frac{E_{r}}{E_{0}}\left(x_{\mathrm{G}, \mathrm{r}}-c\right)^{2}
\end{gathered}
$$


where: $b$ - section width [m]; $h$ - section height $[\mathrm{m}] ; n=E_{1} / E_{0} ; \gamma$ - the ratio of the section height with the E0 module to the total height of the beam; $x_{\mathrm{G}}$ - distance of the neutral axis from the bottom of the beam [m]; $A_{r}$ - reinforcement cross-sectional area $\left[\mathrm{m}^{2}\right] ; E_{r}$ - modulus of longitudinal elasticity of the reinforcement [Pa]; $c$ - distance of reinforcement from the bottom of the beam [m]

Dividing the equation 19 by the moment of inertia of the unreinforced beam $I_{t}$, we obtain the value of the correction factor:

$$
\beta_{r}=1+\frac{3(1-2 \lambda)^{2}}{\beta} \frac{\xi \omega}{\xi+\omega}
$$

where:

$\lambda=c / h$,

$\xi=n-(n-1) \gamma_{1}$

$\omega=\left(A_{r} / A\right)\left(E_{r} / E_{0}\right)$,

$\beta=n-(n-1) \gamma^{3}$

Assuming two possible models of destruction: the destruction of the extreme lamellas with the $E_{1}\left(\sigma_{1}\right)$ module and the destruction of the middle lamellas with the $E_{0}\left(\sigma_{0}\right)$ module, we can obtain:

$$
\begin{gathered}
\sigma_{1}=n \frac{M_{\mathrm{t}, \mathrm{r}}^{a}}{I_{\mathrm{t}, \mathrm{r}}} x_{\mathrm{c}, \mathrm{r}} \\
\sigma_{0}=n \frac{M_{\mathrm{t}, \mathrm{r}}^{b}}{I_{\mathrm{t}, \mathrm{r}}}\left(x_{\mathrm{c}, \mathrm{r}}-\frac{h-h_{1}}{2}\right)
\end{gathered}
$$

where: $h_{1}$ - the height of the wooden part with the module $E_{0}[\mathrm{~m}] ; x_{\mathrm{c}, \mathrm{r}}-$ distance of the neutral axis from the top surface of the beam [m].

The distance of the neutral axis from the top surface of the beam can be determined from the expression:

$$
x_{\mathrm{c}, \mathrm{r}}=h-x_{\mathrm{G}, \mathrm{r}}=\frac{h}{2} \frac{(\xi+\omega)+\omega(1-2 \lambda)}{\xi+\omega}
$$

Assuming that the loss of load-bearing capacity occurs due to the destruction of the outer lamella, the condition shown in formula 24 is obtained. After substituting formula 23 for formula 24 , we obtain the condition 25 . The load capacity for the first model, the failure $M_{\mathrm{t}, \mathrm{r}}^{a}(\mathrm{~N} \cdot \mathrm{m})$ we determine according to formula 26, with the second failure model $M_{\mathrm{t}, \mathrm{r}}^{b}(\mathrm{~N} \cdot \mathrm{m})$ according to formula (27):

$$
\begin{gathered}
\frac{\sigma_{1} I_{\mathrm{t}, \mathrm{r}}}{n x_{\mathrm{c}, \mathrm{r}}} \leq \frac{\sigma_{1} I_{\mathrm{t}, \mathrm{r}}}{x_{\mathrm{c}, \mathrm{r}}-\frac{h-h_{1}}{2}} \Rightarrow \frac{k}{n} \leq \frac{x_{\mathrm{c}, \mathrm{r}}}{x_{\mathrm{c}, \mathrm{r}}-0,5\left(h-h_{1}\right)} \\
\frac{k}{n} \leq \frac{(\xi+\omega)+\omega(1-2 \lambda)}{(\xi+\omega) \gamma+\omega(1-2 \lambda)} \\
M_{\mathrm{t}, \mathrm{r}}=M_{\mathrm{t}, \mathrm{r}}^{a}=\frac{\sigma_{1} I_{\mathrm{t}, \mathrm{r}}}{n x_{\mathrm{c}, \mathrm{r}}} \\
M_{\mathrm{t}, \mathrm{r}}=M_{\mathrm{t}, \mathrm{r}}^{b}=\frac{\sigma_{0} I_{\mathrm{t}, \mathrm{r}}}{x_{\mathrm{c}, \mathrm{r}}-0,5\left(h-h_{1}\right)}
\end{gathered}
$$

\subsection{The method using the balance of forces in the cross-section}

The most universal, widely used and most practical method is the method presented by Borri et al. [6] and by Yang et al. [5]. The main assumptions of the method are presented in Figure 1. 


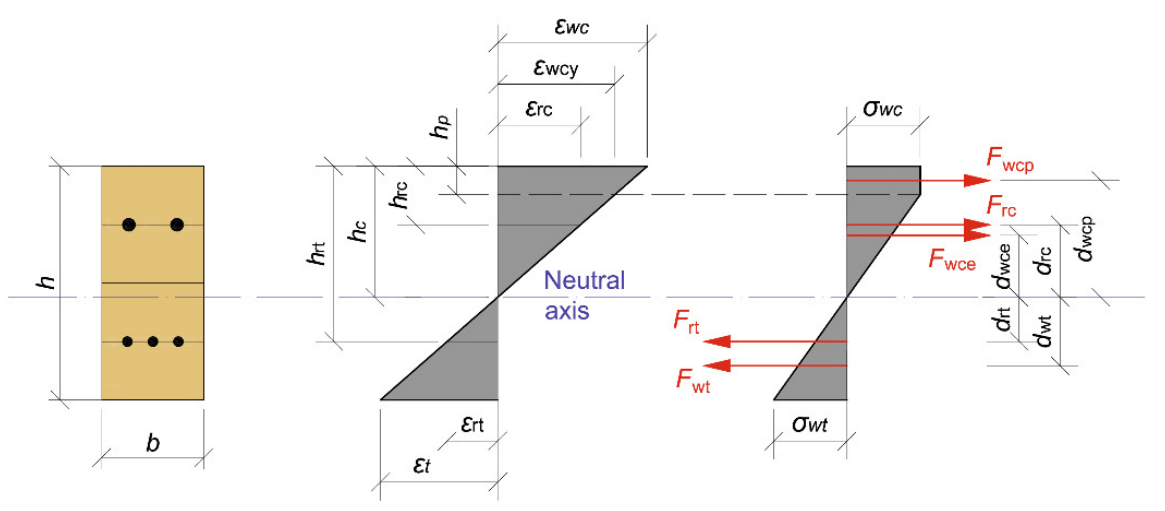

Fig. 1. The assumptions made in the cross-section of the beam with the markings used in the theoretical model (based on the [5])

Two models of failure are considered in the presented method: by exceeding the tensile strength or by exceeding the compressive strength. Assuming the tensile failure model, we assume the cooperation of bars with wood in the tension and compression zones. The difference is that when considering the compression failure model, the interaction of reinforcing materials with wood in the compressed zone of the beam is not taken into account. The forces in the beam (Fig. 1) are determined on the basis of formulas (28)-(32):

$$
\begin{gathered}
F_{\mathrm{rc}}=A_{\mathrm{rc}} \sigma_{\mathrm{rc}} \\
F_{\mathrm{wcp}}=\frac{A_{\mathrm{wcp}}\left(f_{\mathrm{wcu}}+\sigma_{\mathrm{wc}}\right)}{2} \\
F_{\mathrm{wce}}=\frac{A_{\mathrm{wce}} f_{\mathrm{wcu}}}{2} \\
F_{\mathrm{wt}}=\frac{A_{\mathrm{wt}} \sigma_{\mathrm{wt}}}{2} \\
F_{\mathrm{rt}}=A_{\mathrm{rt}} \sigma_{\mathrm{rt}}
\end{gathered}
$$

where: $A_{\mathrm{rc}}$ - cross-sectional area of compression reinforcement $\left[\mathrm{m}^{2}\right] ; \sigma_{\mathrm{rc}}$ - stresses in compression reinforcement [Pa]; $\sigma_{\mathrm{wc}}-$ stresses in wood at the compression edge [Pa]; $A_{\mathrm{cwp}}-$ area of plasticised part of a wooden section [ $\left.\mathrm{m}^{2}\right] ; f_{\mathrm{wcu}}$ - yield point of wood [Pa]; $A_{\mathrm{wce}}-$ area of the compressed part working in the elastic range $\left[\mathrm{m}^{2}\right] ; A_{\mathrm{wt}}$ - area of the tensile part of the wooden section $\left[\mathrm{m}^{2}\right]$; $\sigma_{\mathrm{wt}}-$ stresses in wood at the tension edge [Pa]; $A_{\mathrm{rt}}$ - cross-sectional area of tension reinforcement $\left[\mathrm{m}^{2}\right] ; \sigma_{\mathrm{rt}}-$ stresses in tension reinforcement $[\mathrm{Pa}]$.

The equilibrium equation of the sum of the projections of forces is determined according to:

$$
F_{\mathrm{wt}}+F_{\mathrm{rt}}=F_{\mathrm{rc}}+F_{\mathrm{wce}}+F_{\mathrm{wcp}}
$$

Using the equilibrium equation of the sum of the projections of forces (33), it is possible to determine the position of the neutral axis $h_{c}$ (which will be different for different failure models). The different action arms (Fig. 1) needed to determine the tensile capacity are shown in expressions (34)-(38). The tensile failure model $M_{\mathrm{tf}}(\mathrm{N} \cdot \mathrm{m})$ is calculated according to formula (39):

$$
\begin{gathered}
d_{\mathrm{rc}}=h_{c}-h_{\mathrm{rc}} \\
d_{\mathrm{wcp}}=h_{c}-\frac{2\left(h-h_{c}\right) \varepsilon_{\mathrm{wcy}}+h_{c} \alpha_{m} \varepsilon_{\mathrm{wmu}}}{3\left[\left(h-h_{c}\right) \varepsilon_{\mathrm{wcy}}+h_{c} \alpha_{m} \varepsilon_{\mathrm{wmu}}\right]} h_{p}
\end{gathered}
$$




$$
\begin{gathered}
d_{\mathrm{wce}}=\frac{2\left(h_{c}-h_{p}\right)}{3} \\
d_{\mathrm{wt}}=\frac{2\left(h-h_{c}\right)}{3} \\
d_{\mathrm{rt}}=h_{\mathrm{rt}}-h_{c} \\
M_{\mathrm{tf}}=F_{\mathrm{rc}} d_{\mathrm{rc}}+F_{\mathrm{wcp}} d_{\mathrm{wcp}}+F_{\mathrm{wce}} d_{\mathrm{wce}}+F_{\mathrm{wt}} d_{\mathrm{wt}}+F_{\mathrm{rt}} d_{\mathrm{rt}}
\end{gathered}
$$

When calculating the load capacity with the use of the compression failure model, the force arm is determined using formulas (34), (36)-(38) (for a different value of the height $h_{c}$ ). The value of $d_{\text {wcp }}$ changes (formula (35)), which is determined on the basis of formula (40). The compressive failure resistance $M_{\mathrm{cf}}(\mathrm{N} \cdot \mathrm{m})$ is determined on the basis of the expression (41). The element load capacity $M_{u}(\mathrm{~N} \cdot \mathrm{m})$ is assumed to be lower, from two values determined on the basis of (42).

$$
\begin{gathered}
d_{\mathrm{wcp}}=h_{c}-\frac{2 \varepsilon_{\mathrm{wcy}}+\varepsilon_{\mathrm{wcu}}}{3\left(\varepsilon_{\mathrm{wcy}}+\varepsilon_{\mathrm{wcu}}\right)} h_{p} \\
M_{\mathrm{cf}}=F_{\mathrm{rc}} d_{\mathrm{rc}}+F_{\mathrm{wcp}} d_{\mathrm{wcp}}+F_{\mathrm{wce}} d_{\mathrm{wce}}+F_{\mathrm{wt}} d_{\mathrm{wt}}+F_{\mathrm{rt}} d_{\mathrm{rt}} \\
M_{u}=\min \left\{M_{\mathrm{tf}}, M_{\mathrm{cf}}\right\}
\end{gathered}
$$

\section{Conclusions}

The article presents an overview of the most effective methods for estimating the bearing capacity of glued laminated beams reinforced with fiber composites. These methods are not mathematically complicated and can be used by engineers for design purposes. The presented methods differ in the initial assumptions and the method of deriving individual quantities. According to the authors, the most universal and effective method is the one based on the balance of forces in the cross-section.

\section{References}

[1] Jasieńko J., Połączenia klejowe w rehabilitacji i wzmacnianiu zginanych belek drewnianych, Oficyna Wydawnicza Politechniki Wrocławskiej, Wrocław 2002.

[2] Nowak T., Analiza pracy statycznej zginanych belek drewnianych wzmacnianych przy użyciu CFRP, Rozprawa doktorska, Wrocław 2007.

[3] Fossetti M., Minafò G., Papia M., Flexural behaviour of glulam timber beams reinforced with FRP cords, Construction and Building Materials 2015, 95, 54-64.

[4] Borri A., Corradi M., Grazini A., A method for flexural reinforcement of old wood beams with CFRP materials, Composites: Part B 2005, 36, 143-153.

[5] Yang H., Liu W., Lu W., Zhu S., Geng Q., Flexural behavior of FRP and steel reinforced glulam beams: Experimental and theoretical evaluation, Construction and Building Materials 2016, 106, 550-563.

[6] Borri A., Corradi M., Grazini A., A method for flexural reinforcement of old wood beams with CFRP materials, Composites: Part B 2005, 36, 143-153.

\section{Przegląd modeli analitycznych do szacowania nośności belek drewnianych wzmacnianych kompozytami włóknistymi}

\section{STRESZCZENIE:}

Wykorzystanie kompozytów do wzmacniania konstrukcji drewnianych jest obecnie popularnym rozwiązaniem konstrukcyjnym. Pomimo popularności rozwiązania nadal brak przepisów normatywnych określają- 
cych sposoby szacowania nośności elementów drewnianych wzmacnianych kompozytami. Możliwe jest wykorzystanie metod numerycznych, lecz jest to metoda stosunkowo pracochłonna. W artykule przedstawiono przegląd najbardziej popularnych metod analitycznych służących do szacowania nośności zbrojonych elementów drewnianych.

\section{SŁOWA KLUCZOWE:}

drewno; FRP; kompozyty włókniste; modele obliczeniowe 